\title{
On the Characteristics and Translation Method of the Chinese Verb "Jinxing"
}

\author{
Zhiliang Liu \\ Foreign Language Department of Hui Zhou University, Huizhou, Guangdong, China \\ Lidan Liu \\ Huangbei Middle School, Yingde, Guangdong, China
}

\begin{abstract}
The verb "Jinxing" has been frequently used in contemporary Chinese language. Normally, it is mainly used in political, scientific and economic articles and on some solemn occasions, but it appears rarely in daily conversation and literary works. According to the statistics of Modern Chinese Corpora, the frequency of the usage of "Jinxing" is nearly $\mathbf{0 . 1 1 6 \%}$. Based on its language usage, it could be divided into transitive and intransitive verbs. Based on its part of speech, it could serve as functional verb and dummy verb. As "Jinxing" has so many complicated usages, translators often feel confused during the English-Chinese translation process. Therefore, this paper will introduce examples to help readers to understand the usage of "Jinxing" so as to become capable of distinguishing functional verb from dummy verb and translating it into English properly under different contexts, which leads readers to think deeply of the differences between Chinese and English translation.
\end{abstract}

Index Terms—method of translation, "Jinxing”, dummy verb, functional verb

\section{INTRODUCTION}

There is a kind of verb whose objects are usually the verbs or polarization phrase in modern Chinese language. This kind of words has syntactic and grammatical functions. In other words, they just make the objects of a verb carry specific information but they themselves have no particular meanings. Generally speaking, the common dummy words include “加以”, “给予”, “给以”, “予以”, “进行”, “作” and so on. We call them as dummy words. In recent years, linguists have paid more attention to them, giving them many different names as well as doing many researches. The earliest person to study the dummy words is Mr. Zhu Dexi. In his work The Dummy Words and Noun-verbs in Modern Written Chinese (1988), he made a clear definition of “dummy verbs". As we can see, after the publication of Mr. Zhu's works (ibid), the name and the usage of dummy words have taken great changes in the past years. Therefore, before we start our research, it's necessary for us to review their different names and definitions made by various linguists. So far, the names of the verb "Jinxing" are as follows:

1) dummy verb: Lv Shuxiang (1980) named such words as "dummy verbs".

2) forerunner verb: Fan Xiao (1987) put forward this term in his book An Introduction to Chinese Verbs. The verbs "jiayi", "yuyi", "geiyi", "geiyu" and "zhiyu" have no statement functions like predicates and they are just act as the agents of the real verbs.

3) colorless verb: Song Yuke (1982), in his book, Grammatical Functions of the Verb "Jinxing", argued that the function of colorless verbs were not mainly for meaning but for grammar.

4) "wei-bin" verb: In the book Modern Chinese Language edited by Huang Borong and Liao Xudong (1991), they used that term.

5) functional verb: this term was first used in the book The Discussions on De-lexical Verbs by Yuan Jie and Xia Yunyi(1984).

6) functional verb: Zhu Dexi (1985) used that term in his book functional Verbs and Gerunds in Modern Written Chinese.

Those different terms reflect people's different understanding of the word "Jinxing". To a certain extent, those terms all sound reasonable and have much in common. However, the main purpose of this paper is to discuss the translation method of the word "Jinxing" rather than rectifying its name. Therefore, in order to avoid misunderstanding, I chose the term "dummy word" as its English translation because the usage and influence of that term is relatively large. According to a large number of articles, we found that the researches made by many experts and scholars were usually concentrated on its grammatical features and objects, but they rarely studied its English translation. So in this paper I will use examples to help readers to understand the different translation methods of the word "Jinxing" in different contexts, guiding them to have a more profound thinking of the Chinese-English translation method.

\section{Characteristics OF THE Verb “JinXING”}


We know that the translation of a verb could be different based on its characteristics. So before we analyze the Chinese-English translation method of the verb "Jinxing", it's necessary for us to have a clear understanding of its characteristics so as to translate it properly in different contexts.

\section{A. Dummy Verb}

The term "dummy verb" was first introduced by Lv Shuxiang in 1980, and it is also called "de-lexical verb", "forerunner verb", "colorless verbs", and "wei-bin verbs" and so on. According to Zhu Dexi (1988) and Fan Xiao (1987), the lexical meanings of this kind of verbs have gradually become illusory. In sentences, they form the predicate-object structures whose objects are verbs or focus on verbs. Those structures can make the verb objects bear specific behaviour information and these verb objects will not affect the original meaning of the sentence if we remove them. Therefore, there are three important standards to judge whether "Jinxing" is a dummy word or not. The first standard depends on whether its meaning becomes illusory or not. The second one is whether the object of the verb "Jinxing" is a verb or focuses on verbs as objects or not. The third is whether the verb "Jinxing" will affect the basic meaning of the original sentence if we remove it. So far, there are six dummy verbs which are publicly known by people: "jia-yi", "gei-yi”, “gei-yu”,"yu-yi”, “zuo", “jin-xing”. Liu Yunfeng (2004) said in the book "Dummy Verbs and Its Object" that the word "Jinxing" can have noun objects as well as verb-objects but the verb-objects can not be added with objects.

\section{B. Functional Verb}

Consequently, "Jinxing" can have noun objects as well as verb objects. Normally, these objects include three kinds: double syllable verb, compound phrase and verb objects with modifier. "Jinxing" can be used as a transitive verb as well as an intransitive verb; it also serves as a predicate in a sentence and expresses the meaning of persistent activity. In addition, it undertakes the syntactic and semantic functions. From this point of view, "Jinxing" can be used as a functional verb (including transitive and intransitive verbs ) and dummy verb. When it is followed by the noun object or complement, it is the functional verb; when it is followed by the verb object, it's the dummy verb.

\section{Examples}

Now let's illustrate their uses by the following examples taken from Modern Chinese Corpus and Chinese-English Parallel Corpora made by Shaoxing College of Art and Science (2009).

1) 将爱情进行到底。

2) “培根完全抛弃了、拒绝了经院哲学的方法, 即根据一些极其遥远的抽象的概念进行推理, 作出论断, 建立 哲学理论, 面对摆在眼前的东西视而不见”。

3) 例如, 我国宪法第四十一条第三款规定，人民法院审判案件，除法律规定的特别情况外，一律公开进行; 我国婚姻法第二十五条第二款规定, 人民法院审理离婚案件, 应当进行调解。

In example 1, the complement "dao-di" is added behind "Jinxing". In this case, the word "Jinxing" is served as a functional word.

In example 2, the verb "tui-li" is added behind "Jinxing", so "Jinxing" is a dummy word in this sentence.

In example 3, the first "Jinxing" belongs to the intransitive verb of functional verbs while the second "Jinxing" is a dummy verb as it's added with a verb.

4) 中国男子排球队今晚在这里同欧洲劲旅波兰队进行第二场比赛，以三比一获胜。

5) 中国和古巴女队，是在沿海的中等城市富山进行比赛。

In these two examples, they all contain the word "bi-sai". However, in example 5, the word "bi-sai" is a verb as the meaning of the whole sentence would not change after removing the word "Jinxing". Therefore, in this sentence, "Jinxing" is a dummy verb. But in example 4, the word "bi-sai" is a functional verb and it becomes a noun phrase modifier, while the word "Jinxing" serves as predicate in this sentence, so it's a functional verb.

From the above examples, we can see that the verb "Jinxing" has many different identities in sentences. Therefore, it is very important to translate it from Chinese into English and have a clear understanding of its function in different contexts.

\section{Three Translation Methods OF THE VerB “JinXING”}

According to the above passage, we know the verb "jinxing" could be divided into "dummy verb" and "functional verb". So we have to choose the translation methods properly in order to translate the two kinds of verbs.

A. Omission of Dummy Verb "Jinxing"

In this part, the translation method of omission will be introduced on how to translate the dummy verb "jinxing" under different contexts.

1. "Jinxing" + double syllable verb

A double syllable verb could be added at the end of "Jinxing". In this case, although "Jinxing" works as a predicate, its semantic meaning has become virtual. As a result, the main information of the whole sentence focuses on the objects behind "Jinxing".For example: 
1) 农业生产获得好收成, 种植结构开始进行调整。 (There was a good harvest, and preliminary improvements were achieved in the pattern of farming.)

In this sentence, the verb "tiao-zheng" is added behind "Jinxing". If we remove the verb "tiao-zheng", the sentence is still reasonable. So in this sentence, "jinxing" is a dummy verb. Adding the word "Jinxing" is to make the sentence become complete and grammatically right, but it has no practical meaning. Therefore, we could omit it and don't have to translate it.

2) 虽然未作前瞻性随机试验, 将治疗及未治疗的小儿进行对比, 但大部分研究者的印象是: 如果给予适当抗 生素治疗, 临床病程可以缩短。 (Although no prospective randomized trials have been done to compare treated and untreated children, it is the impression of most investigators that there is a shortened clinical course if an appropriate antimicrobial is prescribed.)

In this sentence, if the original sentence doesn't add the dummy verb “Jinxing” but linking-up the action-object “治 疗及未治疗的小儿”, then the object will look too long and the whole sentence structure would become asymmetric. So we need the verb “Jinxing” to establish the sentence which is led by the prepositions like “对、把、将、就”.

The same examples are as follows:

3) 依法向国有企业派出监事会, 检查企业财务, 对董事、经理的职务行为进行监督, 维护国有资产所有者权 益。(Boards of supervisors should be assigned to state-owned enterprises according to law to examine the financial dealings of enterprises, exercise supervision over the members of the boards of directors and managers performing their duties, and safeguarding their rights.)

Sometimes, intransitive verb is added behind "Jinxing". Generally speaking, the intransitive verb can not take objects. But in some cases, in order to emphasis its action, the sentence needs to use dummy verbs to constructure sentences. Here are the examples:

4) 我们不断对各种颜色进行实验, 直至调配成功。(We experimented until we succeeded in mixing the right color.)

In this sentence, "shi-yan" is an intransitive verb, it needs to emphasize its action object, "ge-zhong-yan-se. But in Chinese, we cann't say "shi-yan--ge-zhong-yan-se", so we have no choice but use dummy verb "Jinxing". As a result, when translating we should ignore the grammatical function of dummy verb and focus on the verb object.

\section{2. "Jinxing" +compound phrase}

Let us have a look at the following examples.

1) 资产重新配置: 将公司的资产重新进行策略分配, 以提高盈利能力. (Asset Play: An incorrectly valued stock that is attractive because its combined asset value greater than its market capitalization.)

2) 围绕制定国家中长期科学和技术发展规划, 组织 2000 多位专家对若干战略问题进行研究论证。(We organized over 2,000 experts to study and discuss a number of strategic issues bearing on the formation of a national medium and long-term program for scientific and technological development.)

In the two sentences, compound phrases are added with "Jinxing" and the sentences are still correct after removing "Jinxing" so we just need to translate the phrases behind the dummy verbs "Jinxing".

\section{3. "Jinxing" + verb objects with modifier}

Sometimes, there will be various modifications in front of verb objects. These modifications could be nouns, adjectives, verbs, locative phrases, numeral phrases, subject-predicate phrases, verb-object phrases, prepositional phrases and adverbs. According to the study of Song Yuke, when these modifications are added behind verbs, the verbs are turned into nouns. For example, “商代的王室和大贵族使用大批奴隶进行农业生产”. In this sentence, "sheng-chan" is added with the noun "nong- ye" and the verb "sheng-chan" can not work as a predicate after it's added with noun modification but it serves as subject or object. However, we know that a complete sentence must have a predicate, so in the above example, we need a predicate which just has grammatical function but without adding more information to the original predicate. In that case, the dummy verb "Jinxing" is the only choice to make that sentence become complete. Consequently, we know that the dummy verb "Jinxing" just undertakes grammatical function and has no practical meaning, so when we translate we don't have to translate it but just focus on the phrases behind "jinxing". For example:

1) 宜于实行股份制的国有大中型企业, 要利用股票市场, 抓紧进行股份制改革。(Large and medium-sized state-owned enterprises to which the stockholding system is applicable should make use of the stock market and quickly implement stockholding system reforms.)

In this sentence, the verb "gai-ge" can no longer work as predicate after it's added with the modification "gu-fen-zhi" although it indicates concrete action. Therefore, we must use the dummy verb "Jinxing" to substitute predicates. When translating this sentence, we still pay our attention to the verb of the verb-object phrase "gai-ge" while the noun modification "gu-fen-zhi" serves as object in this sentence.

The similar examples are as follows.

2) 我们要加快推进行政管理体制改革, 进一步转变政府职能。(We will accelerate reform of the administrative system and further transform government functions.)

3) 以前的病例研究对评价持续阻塞性黄疸的实验室检查已进行过一定程度的讨论。(The laboratory studies performed in the evaluation of prolonged obstructive jaundice have been discussed to some extent in the prior case 
study.)

4) 继续加强文化市场和互联网的建设与管理, 坚持不解地进行“扫黄”, “打非”斗争。 (We will continue to strengthen the development and management of the market for cultural products and the Internet, fight unremittingly against pornographic and illegal publications.)

In the last two sentences, the the verbs "tao-lun" and "dou-zheng" are added with the adjective "yi-ding-cheng-du-de" and verb-object phrase "sao-huang-da-fei" and they turned into nouns and can no longer be regarded as predicates. So we need to use "Jinxing" to build up this sentence and have no need to translate "Jinxing".

From the above examples we could draw the following conclusion. Based on the dummy verb's syntactic and grammatical functions in Chinese, we could omit the translation of "Jinxing" and focus on the verb-object phrase. Further more, not only does this method measure up to the expressional manners of English language but also presents the original information completely.

\section{B. Functional Verb "Jinxing" as Corresponding Verbs}

The Chinese verb "jinxing" means undertaking some certain activities in Modern Chinese Dictionary (2006). But in A New Century Chinese-English Dictionary Chinese-English Dictionary (2009), this verb can be translated as "underway, progress, go on, proceed, do, carry out/on, conduct, make, hold, take" and so on. In the following, examples will be given to analyze the various English expressions of the verb "jinxing" which are quite common in our life.

\section{As "do"}

1) 然后进行手术性胆管造影以观察远端胆道系统。 (Operative cholangiography is then done in order to observe the distal biliary system.)

2) 进行这项调整，要综合运用经济、法律和必要的行政手段，充分发挥市场机制的作用。 (To do this, we will use a combination of economic, legal and necessary administrative means, and take full advantage of the role of market forces.)

In the above examples, we use the verb "do" to translate the functional verb "jinxing". According to the Oxford Advanced Learner's English-Chinese Dictionary (2010), the verb "do" refers to work at or perform an activity or a task. Therefore, we can use "do" to translate the verb "jinxing".

\section{As "take"}

1) 在体外循环(完全性心肺分流术)下, 为患儿进行了手术, 用一种涤纶片封闭了膜部室间隔缺损。(The patient was taken to surgery where, under total cardiopulmonary bypass, her membranous ventricular septal defect was closed using a Dacron patch.)

2) 治疗开始 4 周后, 进行胸部 X 线检查显示心脏体积缩小。 (The chest X-ray taken 4 weeks after the beginning of treatment reveal marked reduction in heart size.)

In the above two sentences, "take" means using a particular course of action in order to deal with or achieve something. From its definition, we could see that using the verb "take" to translate the verb "jinxing" mainly aims to achieve something.

\section{As "process" and "proceed"}

1) 重视农村卫生设施建设, 稳步进行新型农村合作医疗制度试点。 (We put a lot of effort into building health facilities in rural areas, a new system of rural cooperative medical and health care services progressed steadily.)

2) 他们一直被告知说救援工作进行得很顺利。(They have been told that rescue operations are progressing smoothly.)

3) 大型招待会正在进行。(A great reception is in progress.)

4) 这项工作, 当然要有步骤地进行, 但是太慢了不行。(We should, of course, proceed with this work methodically buy not too slowly.)

5) 灾区群众生活得到妥善安排, 恢复生产和重建工作有序进行。(As a result, proper living arrangements were made for people in disaster-afflicted areas, production resumed and reconstruction proceeded in an orderly way.)

6) 邮政体制改革顺利进行, 电力、电信、民航、铁路等行业改革取得积极进展。 (Reform of the postal service system proceeded smoothly, and encouraging progress was made in reforming the power, telecommunications,civil aviation and railway industries.)

7) 中国农业银行和国家开发银行股份制改革顺利进行。(The transform of the Agriculture Bank of China and China Development Bank into joint stock companies proceeded smoothly.)

In these sentences, the verb "progress" and "proceed" are synonyms as well as intransitive verbs. But the former means improving or developing over a period of time, making progress while the latter means carrying on or continuing any action or process. Therefore, when the verb "jinxing" bears those meanings and serves as intransitive verb, we could use the verbs progress and proceed in translation

\section{As "conduct"}

1) 对此患儿在学校及邻居中的接触者进行了广泛的检查。(An extensive testing of this patient's contacts at school and in the neighborhood was conducted.)

2) 我们愿意在这个原则基础上, 进行海峡两岸的对话与谈判, 什么问题都可以谈。(On the basis of this principle, we are willing to conduct cross-straits dialogue and negotiations on any matter.) 
3) 今年各地要对最低工资制度和小时最低工资标准的执行情况, 普遍进行一次检查。(All local governments should conduct a general survey of compliance with the minimum wage system and minimum wage standards for part-time workers.)

Among these sentences, conduct means organizing or doing a particular activity. Therefore, when the verb "jinxing" is added with phrases which means some certain particular activities, we could use the verb "conduct" in translation

5. As "perform"

1) 给患儿进行了经皮肾穿刺活组织检查, 并确定为微小病变型肾病。(A percutaneous renal biopsy was performed and minimal change nephropathy was identified.)

2) 但此时进行的健康婴儿检查未观察到黄疸。(However, a well-baby examination was performed, and no jaundice was noted at that time.)

3) 医生选择立即进行如下实验。(The physician elects to perform the following tests immediately.)

When the phrase behind the verb "jinxing" means a piece of work, task, or duty, we could use the verb "perform" in translation.

\section{As "undertake"}

1) 买入对冲：商品投资者就期货合约牵涉商品价格上升进行对冲的交易。(Buying Hedge: A transaction that commodities investors undertake to hedge against possible increases in the prices of the actual underlying the futures contracts.)

2) 申请注册为专门承建商的人须令建筑事务监督信纳他具备所需的经验及(如适当)专业与学术资格, 以进行 专门类别的工程。(An applicant for registration as a specialist contractor must satisfy the Building Authority that he has the necessary experience and, where appropriate, professional and academic qualifications, to undertake work in the specialist category.)

3) 处长收到第 4 条所述的报告后, 可授权一名特派调解员发起或承担进行特别调解。(On receipt of a report under section 4, the Commissioner may authorize a special conciliation officer to initiate or undertake special conciliation.)

4) 第(2)款并不禁止第 1 或 2 级注册承办商由同一级别的注册承办商代他承担进行任何工程。 (Nothing in paragraph (2) shall prohibit any work being undertaken on behalf of a registered contractor registered in class 1 or 2 by another registered contractor registered in the same class.)

"Undertake" means making yourself responsible for something and start doing it. In the above sentences, the verb "jinxing" are all containing this meaning. So it's suitable to use the verb "undertake" in translation.

\section{Conversion of the Part of Speech of Functional Verb "Jinxing”}

With the differences between Chinese and English in grammar and expression manners, sometimes we need to change the part of speech of words but also need to guarantee that those changes having no effect on the original meaning. This translation method includes nouns converted into verbs, prepositions into verbs, adjectives into verbs, adverbs into verbs, verbs into nouns, adjectives into nouns, pronouns into nouns, verbs into prepositional phrases and so on. In this part, the method as verbs converted into prepositional phrases will be given to analyze the following sentences.

1) 积极推进农村税费改革, 从根本上减轻农民负担, 今年将在安徽省进行试点, 总结经验后再行展开. (We must promote reform of taxes and charges in rural areas to substantially lighten the burden on farmers. Experiments will be carried out in Anhui Province this year so that the work can be done in other parts of the country after the results of the experiments are analyzed.)

2) 依法打击民族分裂活动、宗教极端势力、暴力恐怖活动、邪教和利用宗教进行非法活动。 (We must use legal means to combat ethnic separatist activities, religious extremist forces, violent and terrorist activities, cults, and illegal activities carried out under the guise of religion.)

3) 按计划进行。(Go forward as planned.)

4) 试验将在地下 400 米处进行。(The test will take place 400metres below the ground.)

5) 进行抵抗。(Put up a resistance.)

In the above examples, the verb "Jinxing" serves as different verbs in those sentences. However, after being translated into English, it's served as propositional phrases in the translation. So it's the application of the conversion of the part of speech. This kind of translation method flexibly changes the part of speech of the verb in target language. That is to say, we don't have to translate every word from source language into target language. On the contrary, we could make some adjustments accordingly.

\section{CONCLUSION}

Translation is a cross-cultural communicative activity whose task is to regenerate the significance of the source language. The meaning and the grammatical function of the same verb "Jinxing" is different when it's put into different contexts. Therefore, we can not just simply use one or several equivalent words in the target language to translate it. From the above analysis on the translation methods of the verb "Jinxing", we have drawn some conclusions. 
1) When translating the verb "Jinxing" from Chinese into English, the first step we should do is to judge and analyze its characteristics, that is to say, whether the sentence is still reasonable or not after removing the verb "Jinxing". If it's so, then the verb "Jinxing" is a dummy verb. Otherwise, it's a functional verb.

2) After we've known about its characteristics, the next step is to choose a suitable translation method. If the verb "Jinxing" is a dummy verb, we use omission method to translate it, as this method could make the translation become suitable for the syntactic structure of target language and present the original meaning. If the verb "Jinxing" is a functional verb, we could use the corresponding words in target language like "carry out, do, conduct, perform, progress, undertake, proceed" to translate it.

3) Conversion of the part of speech is also one of the methods used in translation when the verb" Jinxing" is a functional one. With the differences between Chinese and English in grammar and expression manners, sometimes we not only need to change the part of speech of words but also guarantee that those changes having no effect on the original meaning.

So far, we have discussed and analyzed mainly about the classification on the part of speech of the Chinese verb "jinxing" and the three kinds of translation methods (omission, translating into corresponding verbs, and conversion of the part of speech) However, we should know that these methods are not almighty. Therefore, further research and studies should be done on it and more translation methods will be discovered and found for sure in the future.

\section{REFERENCES}

[1] Fan Xiao. (1987). An Introduction to Chinese Verbs. Shanghai: Shanghai Foreign Language and Education Press.

[2] Foreign Language Department of Shaoxing College of Art and Science. (2009). Modern Chinese Corpus and Chinese-English Parallel Corpora.

[3] Hornby.A.S. (2010). Oxford Advanced Learner's English-Chinese Dictionary. Beijing: The Commercial Press, Oxford: Oxford University Press.

[4] Huang Borong \& Liao Xudong. (1991). Modern Chinese Language. Beijing: Higher Education Press.

[5] Hui Yu. (2009). A New Century Chinese-English Dictionary Chinese-English Dictionary. Beijing: Foreign Language Teaching and Research Press.

[6] Liu Yunfeng. (2004). Dummy Verbs and Its Object. Chongqin: The Press of Southwestern China Minority University.

[7] Lv Shuxiang. (1980). Eight Hundred Words in Modern Chinese. Beijing: Commercial Press.

[8] Modern Chinese Dictionary Editorial Office of Chinese Academy of Social Science. (2006). Beijing: The Commercial Press.

[9] Song Yuke. (1982) Grammatical Functions of the Verb "Jinxing". Language Teaching and Research 1, 59-61.

[10] Yuan Jie \& Xia Yunyi. (1984). The Discussions on Functional Verbs. Language Study 2,231-232.

[11] Zhu Dexi. (1985) Functional Verbs and Gerunds in Modern Written Chinese. Journal of Beijing University 5, 10-11.

[12] Zhu Dexi. (1988). The Dummy Words and Noun-verbs in Modern Written Chinese. Beijing: Beijing University Press.

Zhiliang Liu was born in Wuqi, Shaanxi Province, China in 1964. He received his M.Ed. degree in applied linguistics from Northwest Normal University, China.

He is currently a professor in the Foreign Language Department of Hui Zhou University, China. His research interests include second language acquisition and translation studies.

Lidan Liu was born in Yingde, Guangdong Province, China in 1990. She received her BA degree in English linguistics and literature from Foreign Language Department of Hui Zhou University. She is now a middle school English teacher in Huangbei Middle School, Yingde, Guangdong Province. 